\title{
Seasonal Occurrence and Food Resource Use of an Assemblage of Nearshore Fish Species in the Bothnian Sea, Sweden
}

\author{
Staffan Thorman and Anne-Marie Wiederholm \\ Department of Zoology, Uppsala University, Box 561, S-751 22 Uppsala, Sweden
}

\begin{abstract}
Temporal distribution, food selection, body size and growth periodicity of the fishes Pungitius pungitius, Gasterosteus aculeatus, Pomatoschistus microps, Pomatoschistus minutus, Gobius niger and Phoxinus phoxinus were studied in southern Bothnian Sea $\left(=5 \% \mathrm{~S}_{;}>15^{\circ} \mathrm{C}\right.$ during $1.5 \mathrm{mo}$ ) The hypothesis was tested that competition for food acts as important structuring factor of nearshore fish assemblages. In spite of fluctuations in species numbers and relative abundances during the season, species diversity remained relatively stable. No differences in mean food-niche widths were detectable between adults of each species; however, between juveniles such differences occurred. No correlations were found between mean food overlaps and food-niche widths or species diversity. No evidence could be found that would identify food competition as important structuring factor. In contrast, for a nearshore fish assemblage on the Swedish west coast, competitive interactions for food played, at least temporarily, an important role. Extreme abiotic conditions appear to keep the Bothnian fish populations below the abundance level at which food shortage could become an important selective force.
\end{abstract}

\section{INTRODUCTION}

In general, abiotic conditions, resource availability, competition, and predation have been shown to be important factors influencing the structure of fish assemblages (e.g. Nilsson, 1960; Brett, 1970; Lemmetyinen, 1973; Adams, 1976; Svärdson, 1976; Kislalioglu and Gibson, 1977; Werner and Hall, 1977).

It is difficult to verify that competition acts as a structuring mechanism in natural communities (Connell, 1975, 1980). Controlled field experiments (Connell, 1975) are the only way to examine the impact of competition. Such experiments are difficult to conduct in most environments, because of the complex interactions occurring between species and the openness of the system. Alternatively, competitive interactions may be inferred from niche widths, overlap values, resource uses, species diversity and changes in these measures (Colwell and Futuyma, 1971; MacArthur, 1972; Cody, 1974; Roughgarden, 1974).

The shallow waters of the Bothnian Sea feature exceptional abiotic conditions, i. e. very low salinities and low temperatures. Such a situation offers an oppor- tunity for assessing the role, if any, of competitive interactions in a stressful environment and of comparing the results with those of a parallel study conducted on the Swedish west coast with the same fish species predominating (Thorman, 1982). In the west-coast estuary, competitive interactions for food appeared to play, at least temporarily, an important role. There are only a few studies of the temporal distribution and trophic relationships of the fish species inhabiting the shallow waters of the Baltic and Bothnian Seas (Lemmetyinen, 1973; Anéer and Nellbring, 1977; Zander, 1979).

In this study we explore temporal distribution and food selection of the 6 most abundant small-sized fish species in a shallow bay in the Bothnian Sea, Sweden, i.e. tenspined stickleback Pungitius pungitius (L.), threespined stickleback Gasterosteus aculeatus L., common goby Pomatoschistus microps Krøyer, sand goby Pomatoschistus minutus (Pallas), black goby Gobius niger (L.) and minnow Phoxinus phoxinus (L.), in order to test the hypothesis that competition for food also acts as an important structuring factor in our study area. 


\section{STUDY AREA AND METHODS}

We studied a wave-sheltered, non-tidal bay in the southern Bothnian Sea near the island Väddö $\left(60^{\circ} 07^{\prime} \mathrm{N}\right.$ $18^{\circ} 48^{\prime} \mathrm{E}$ ), at depths of 0.5 to $1.2 \mathrm{~m}$. The bottom consisted of muddy sand with patches of submerged vegetation, primarily Potamogeton spp. L. and Myriophyllum sp. L. Phragmites communis Trin. grew along the shoreline

The salinity in the southern Bothnian Sea is about $5 \% \mathrm{~S}$, rendering this area an extreme environment with pronounced changes in important hydrochemical properties, resulting in an eco-physiological barrier between limnic and marine species (Khlebovich, 1968).

During the year of sampling, 1980, the area was ice covered for about $4.5 \mathrm{mo}$. The period with water temperatures $\geq 15^{\circ} \mathrm{C}$ lasted about 1 to $1.5 \mathrm{mo}$; a maximum temperature of $25^{\circ} \mathrm{C}$ was measured in July (Table 1). These values agree well with the normal situation in the southern Bothnian Sea (Wändahl and Bergstrand, 1973).

Fish samples were hand-trawled monthly during daytime on 7 occasions between April and October, 1980. The trawl (mesh size: $2 \mathrm{~mm}$, opening: $2 \mathrm{~m}$ ) was drawn over a distance of $50 \mathrm{~m}$ at a depth of 0.5 to $1.2 \mathrm{~m}$.

Newly caught fish were anaesthetized immediately in MS 222 and preserved in $4 \%$ formaldehyde. The total fish length was measured to separate juveniles $(0+)$ from adults (exception: Phoxinus phoxinus). Stomach contents were analysed and quantified using a fullness scale $(0,25,50,75,100 \%)$ combined with a scale ranging from 0 to $100 \%$ indicating the proportion of each prey organism in the stomachs.

Species diversity and food-niche width were calculated using the antilogarithm of Shannon-Weaver's index, $\operatorname{Exp}(\mathrm{H})$ (Shannon and Weaver, 1949). Evenness was obtained as $\operatorname{Exp}(\mathrm{H}) / \mathrm{S}$, where $\mathrm{S}=$ number of species. Food overlaps were estimated according to Eq. 1 in Hurlbert (1978),

$$
C_{x y}=\Sigma \min \left(p_{x i}, p_{y l}\right)
$$

where $p_{x i}=$ relative frequency of observations for the food category $i$ in species $x_{i} p_{y_{i}}=$ corresponding frequency in species $y$.

Other fishes were caught sporadically in low numbers, amounting to less than $1 \%$ of the total catch, i. e. perch Perca fluviatilis L., pike Esox lucius (L.), sea scorpion Myoxocephalus scorpius (L.), eelpout Zoarces viviparus (L.), flounder Platichthys flesus (L.), broadnosed pipefish Siphonostoma typhle (L.), baltic herring Clupea harengus var. membras (L.), sprat Sprattus sprattus (L.) and sand eel Ammodytes lancea Yarell.

\section{RESULTS}

\section{Seasonal Distribution}

The smallest numbers of individuals were captured in spring. During summer the populations increased through juvenile recruitment, reaching a maximum in August (Table 1), which corresponds with the general seasonal resource peak at that time. Juveniles comprised more than $85 \%$ of the specimens caught in July and August. Pungitius pungitius, Pomatoschistus microps and $P$. minutus were abundant throughout all months (Fig. 1). P. pungitius was the most numerous species from April to June and in October. After July no adults of $P$. pungitius were caught. $P$. microps was the second most abundant species and the juveniles were most numerous in August and September. The distribution of $P$. minutus was rather even over the season, except for July when the species was almost absent, and in September when the numbers were higher than earlier. Adult Gasterosteus aculeatus appeared in low numbers in spring, while juveniles occurred in summer; no members of this species were caught after August. Phoxinus phoxinus was most abundant in October, and adults of Gobius niger were caught sporadically in spring and juveniles in August (Fig. 1).

In spite of the fluctuations in species numbers and relative abundances during the season, species diversity remained relatively stable (Table 1 ). The evenness was low in April and May which reflects the domi-

Table 1. Fish assemblage in the southern Bothnian Sea. Abundance (individuals $10 \mathrm{~m}^{-2}$ ), proportion of juveniles, diversity and evenness

\begin{tabular}{lcccccccc}
\hline & Apr & May & Jur & Jul & Aug & Sep & Oct \\
\hline Abundance (ind. 10 $\left.\mathrm{m}^{-2}\right)$ & 15 & 26 & 17 & 73 & 123 & 41 & 31 \\
Juveniles (\%) & - & - & - & 96 & 89 & 83 & 69 \\
Diversity & 2.74 & 3.18 & 3.57 & 3.02 & 4.58 & 3.92 & 3.57 \\
Evenness & 0.55 & 0.53 & 0.89 & 0.76 & 0.76 & 0.78 & 0.71 \\
Temperature $\left({ }^{\circ} \mathrm{C}\right)$ & 4.5 & 10 & 15 & 25 & 13 & 13 & 6.5 \\
\hline
\end{tabular}




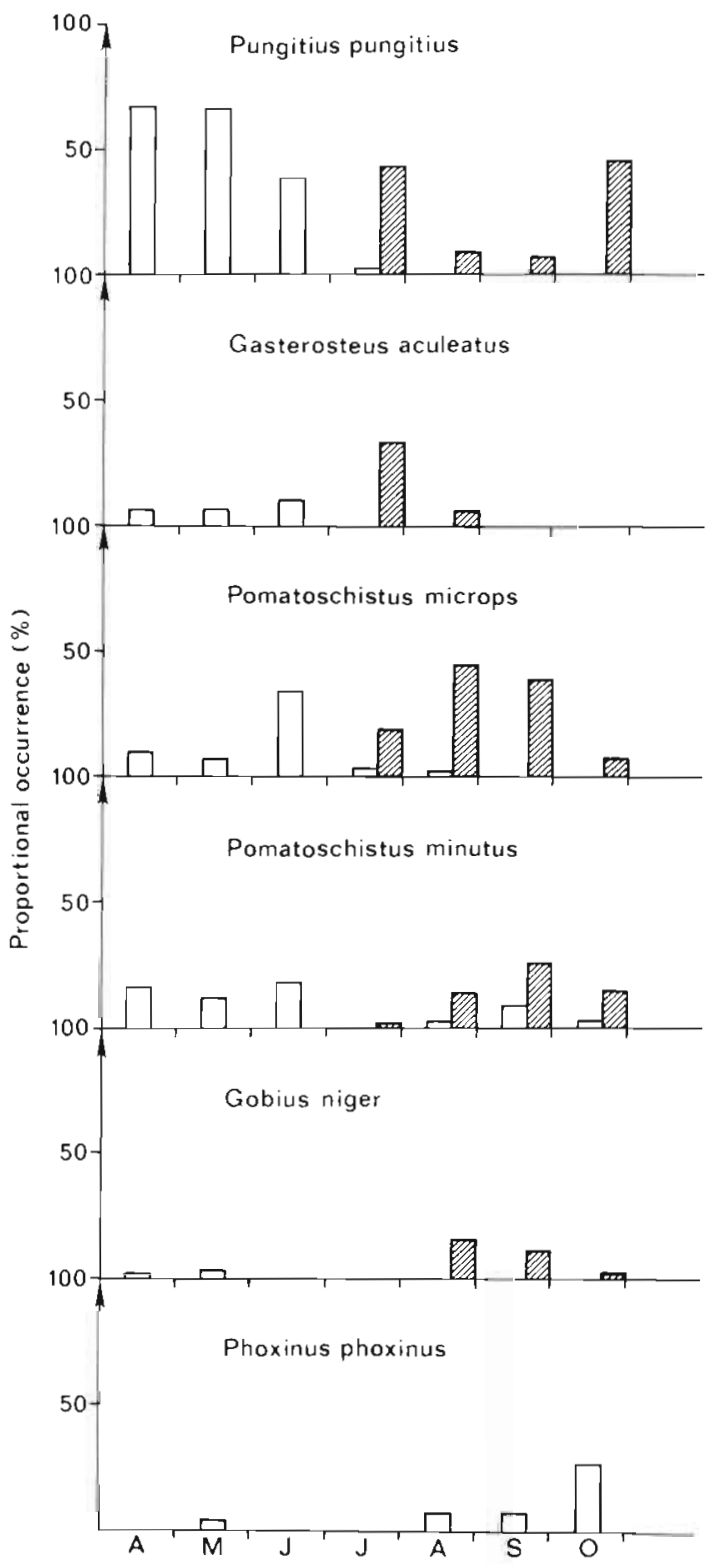

Fig. 1. Monthly proportional occurrence (\%) of each of the fish species studied in the assemblage at Väddö, southern Bothnian Sea. Filled bars: juveniles $(0+)$; open bars: adults

nance of one species, viz. Pungitius pungitius, during these months.

\section{Food Habits}

In April the fishes consumed a variety of prey organisms, such as mysids, gammarids, ostracods and zooplankton (Fig. 2). Chironomids were frequently eaten by adults; in May this prey was the most important one for all tested fish species present. Gasterosteus aculeatus had eaten fish eggs in June. This species is known to prey on its own offspring and to raid eggs from each other's nests (Rohwer, 1978). Zooplankters were frequently eaten by juveniles in July. Later in the season both zooplankters and ostracods occurred frequently in the diet.

\section{Food Niche Width}

The mean adult food-niche width in each of the species studied was wider than in juveniles (MannWhitney U-test, $\mathrm{p}<0.016$; Table 2). No pattern of seasonal changes in niche widths can be seen among the adults, except in June when Pungitius pungitius, Gasterosteus aculeatus, Pomatoschistus microps and $P$. minutus all featured maximum niche widths compared to other months (Mann-Whitney U-test, $p<0.002$ ). In contrast, juveniles increased their niche widths as they grew. No significant differences in mean niche widths could be detected between adults of each species (ANOVA, $\left.F_{4,16}=1.48, N S\right)_{;}$however, between juveniles such differences occurred (ANOVA, $F_{4,12}=$ 69.52, $p<0.001)$. A Neuman-Keul test on juveniles showed that Gobius niger had the widest niche $(p<0.01)$ and $G$. aculeatus the narrowest niche $(p<0.01)$ compared to the other species. Food-niche widths were not correlated with stomach fullness, number of individuals of each species, or their proportional abundances.

\section{Resource Use Overlap}

The mean food overlap for adults increased during spring and reached a maximum in July (0.71) (Table 3 ). When juveniles appeared in July mean food overlaps were high $(0.74)$; they then decreased to a low value in October $(0.27)$. Throughout the season, mean overlaps for each species pair did not exceed 0.62 , except for juveniles of Gasterosteus aculeatus and Pomatoschistus minutus which had an overlap of 0.91 . In June $P$. minutus overlapped broadly with both Pungitius pungitius (0.80) and Pomatoschistus microps (0.75), respectively. No correlations were found between mean food overlaps and food-niche widths, or species diversity.

\section{DISCUSSION}

The most abundant species in the Bothnian fish assemblage - Pungitius pungitius, Pomatoschistus microps, P. minutus and Gasterosteus aculeatus - all exhibit similar life-history patterns with short life spans ( 2 to $4 \mathrm{yr}$ ), reproductive territories, nest building activities and parental care. The sticklebacks maintain 

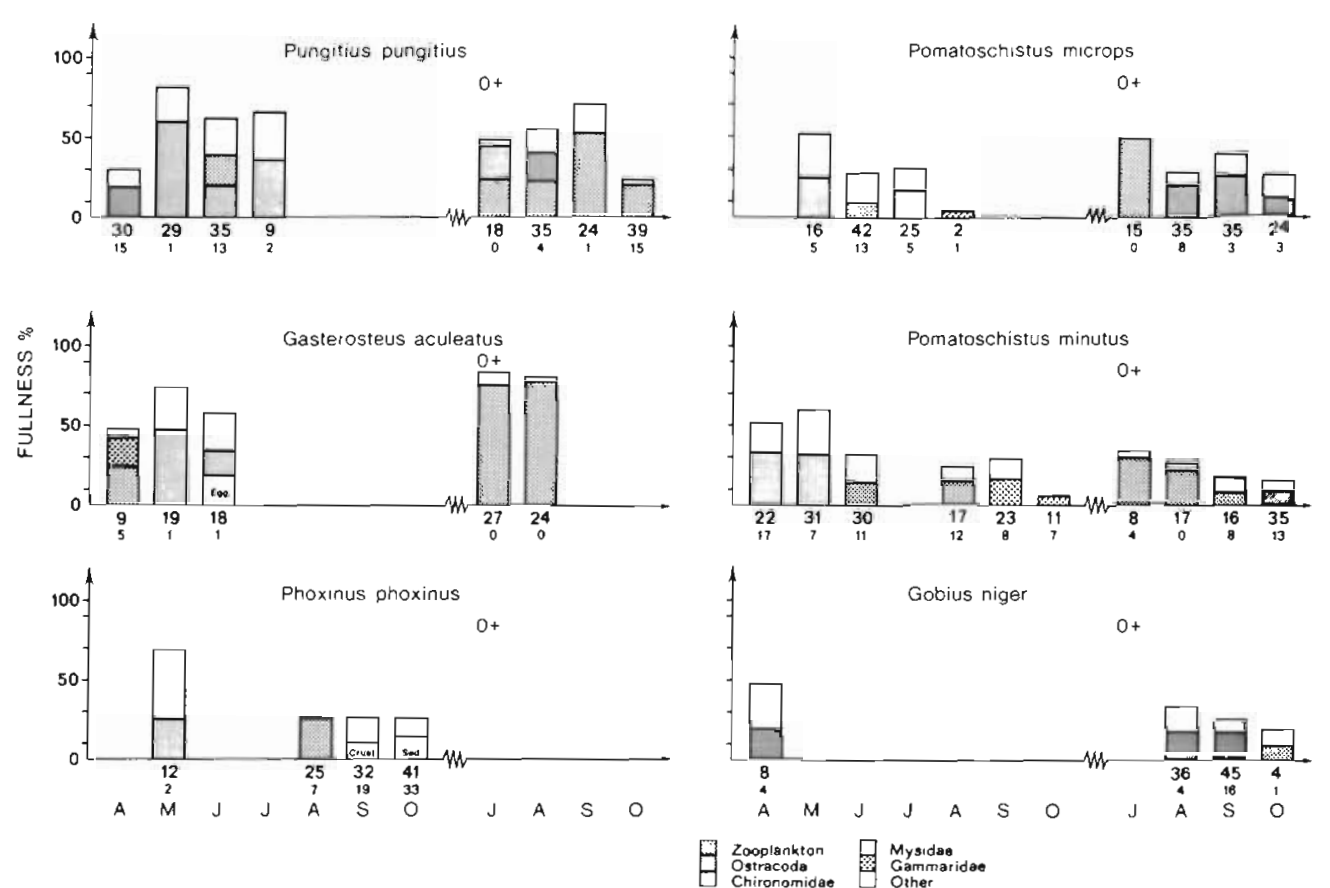

Fig. 2. Major food organisms and stomach fullness (\%) of fish for each month at Väddö. Juveniles separated (except Phoxinus phoxinus) from adults. Large numbers beneath each diagram indicate number of stomachs analysed; small numbers, empty stomachs

schooling behaviour, except during the reproductive season, but the gobies remain solitary.

These 4 species spawn in the study area at the same time. This might limit the numbers of individuals which the area can support simultaneously. The wide food niches during the spawning season in June may be a result of territorial behaviour. This behaviour limits the search time and area; consequently, the fish have to eat a wide variety of prey organisms within their restricted range.

Is competition for food a significant structuring factor for the fish community in the present area, as it seemed to be in a similar fish assemblage on the Swedish west coast (Thorman, 1982)?

Table 2. Food-niche widths (Exp [H]) of fish species studied, and of the whole assemblage. Total niche width is based on the niche width of each species, weighted against its proportional abundance; it therefore reflects the total resource use of the fish assemblage. $0+$ juveniles

\begin{tabular}{|c|c|c|c|c|c|c|c|c|}
\hline Species & Apr & May & Jun & Jul & Aug & Sep & Oct & Mean \pm (S.D.) \\
\hline $\begin{array}{r}\text { Pungitius pungitius } \\
0+\end{array}$ & $\begin{array}{c}2.43 \\
\ldots\end{array}$ & ${ }^{3.37}$ & 4.21 & $\begin{array}{l}3.39 \\
2.69\end{array}$ & 3.73 & 2.23 & 1.45 & $\begin{array}{ll}3.35 & (0.63) \\
2.52 & (0.82)\end{array}$ \\
\hline $\begin{array}{c}\text { Gasterosteus aculeatus } \\
0+\end{array}$ & $\begin{array}{l}2.67 \\
\ldots .\end{array}$ & $\begin{array}{r}3.47 \\
\quad\end{array}$ & $\begin{array}{l}5.93 \\
\cdots .\end{array}$ & 1.46 & 1.07 & & & $\begin{array}{l}4.02(1.39) \\
1.26(0.28)\end{array}$ \\
\hline $\begin{array}{c}\text { Pomatoschistus microps } \\
0+\end{array}$ & & 3.84 & 5.91 & $\begin{array}{l}3.46 \\
1.00\end{array}$ & $\begin{array}{l}2.66 \\
1.00\end{array}$ & 3.39 & 4.00 & $\begin{array}{ll}3.98 & (1.20) \\
2.50 & (0.65)\end{array}$ \\
\hline $\begin{array}{c}\text { Pomatoschistus minutus } \\
0+\end{array}$ & 2.50 & $\begin{array}{l}4.16 \\
\cdots\end{array}$ & $\begin{array}{r}4.21 \\
.\end{array}$ & 1.49 & $\begin{array}{l}3.31 \\
1.62\end{array}$ & $\begin{array}{l}3.55 \\
2.56\end{array}$ & $\begin{array}{l}1.00 \\
3.05\end{array}$ & $\begin{array}{ll}3.12 & (1.11) \\
2.28 & (0.65)\end{array}$ \\
\hline Gobius niger & . & $\begin{array}{c}4.23 \\
.\end{array}$ & . & . & 4.23 & 3.23 & 2.75 & $\begin{array}{l}4.23(0.00) \\
3.40 \quad(0.76)\end{array}$ \\
\hline Phoxinus phoxinus & & 4.06 & & & 1.00 & 4.27 & 2.50 & $2.96(1.53)$ \\
\hline $\begin{array}{l}\text { Total niche width } \\
\text { of fish assemblage } \\
\qquad+\end{array}$ & $\begin{array}{l}3.96 \\
\ldots .\end{array}$ & $\begin{array}{c}4.57 \\
.\end{array}$ & $\begin{array}{c}6.97 \\
\ldots\end{array}$ & $\begin{array}{l}3.62 \\
1.99\end{array}$ & $\begin{array}{l}1.44 \\
4.18\end{array}$ & $\begin{array}{l}5.86 \\
5.09\end{array}$ & $\begin{array}{l}2.59 \\
3.14\end{array}$ & $\begin{array}{ll}4.14 & (1.74) \\
3.60 & (1.16)\end{array}$ \\
\hline
\end{tabular}


Table 3. Food overlap $\left(C_{x y}\right)$ between all species pairs studied in each month. $0+$ juveniles; dashes: 1 of the species absent

\begin{tabular}{|c|c|c|c|c|c|c|c|c|c|}
\hline Species & & Apr & May & Jun & Jul & Aug & Sep & Oct & $\begin{array}{l}\text { Mean food overlap } \\
\text { for each species } \\
\text { pair. } C_{x y} \pm \text { S.D. }\end{array}$ \\
\hline \multicolumn{10}{|l|}{ P.pungitius } \\
\hline G. aculeatus & $0+$ & 0.49 & $\begin{array}{c}0.55 \\
\ldots \ldots\end{array}$ & $\begin{array}{l}0.26 \\
\ldots\end{array}$ & $-\overline{60}$ & 0.40 & - & $\begin{array}{l}- \\
-\end{array}$ & $\begin{array}{ll}0.43 & (0.12) \\
0.50 & (0.10)\end{array}$ \\
\hline P. microps & $0+$ & $\begin{array}{ll} & - \\
\ldots & \ldots\end{array}$ & $\begin{array}{l}0.47 \\
\ldots \ldots\end{array}$ & $\begin{array}{c}0.68 \\
\ldots \ldots\end{array}$ & $\begin{array}{l}0.71 \\
0.50\end{array}$ & $\overline{0.54}$ & $-\overline{23}$ & $\overline{0 .}$ & $\begin{array}{ll}0.62 & (0.11) \\
0.35 & (0.17)\end{array}$ \\
\hline P. minutus & $0+$ & $\begin{array}{c}0.22 \\
\ldots \ldots\end{array}$ & $\begin{array}{l}0.56 \\
\ldots \ldots\end{array}$ & $\begin{array}{l}0.80 \\
\ldots \ldots\end{array}$ & $-\overline{6}$ & $\begin{array}{c}- \\
0.54\end{array}$ & - & $\overline{0.12}$ & $\begin{array}{ll}0.53 & (0.24) \\
0.46 & (0.20)\end{array}$ \\
\hline G. niger & $0+$ & $\begin{array}{c}- \\
\ldots \ldots\end{array}$ & $\begin{array}{l}0.57 \\
\ldots \ldots\end{array}$ & $\begin{array}{c}- \\
\ldots \ldots\end{array}$ & $\begin{array}{c}- \\
\ldots \ldots\end{array}$ & 0.57 & 0.28 & $\begin{array}{c}- \\
0.50\end{array}$ & $\begin{array}{l}0.57 \\
0.45 \quad(0.12)\end{array}$ \\
\hline P. phoxinus & & - & 0.43 & - & - & - & - & - & 0.43 \\
\hline \multicolumn{10}{|l|}{ G. aculeatus } \\
\hline P. microps & $0+$ & $\begin{array}{c}- \\
\ldots \ldots\end{array}$ & $\begin{array}{l}0.18 \\
\ldots .\end{array}$ & $\begin{array}{l}0.26 \\
\quad \ldots \ldots\end{array}$ & $\overline{0 .}$ & $\overline{0 .}$ & $\begin{array}{l}- \\
-\end{array}$ & $\begin{array}{l}- \\
-\end{array}$ & $\begin{array}{ll}0.22 & (0.04) \\
0.52 & (0.38)\end{array}$ \\
\hline P. minutus & $0+$ & $\begin{array}{l}0.28 \\
\ldots \ldots\end{array}$ & $\begin{array}{l}0.76 \\
\ldots \quad \ldots\end{array}$ & $\begin{array}{c}0.26 \\
\ldots \ldots\end{array}$ & $\overline{0.94}$ & $-\overline{87}$ & - & - & $\begin{array}{ll}0.43 & (0.23) \\
0.91 & (0.04)\end{array}$ \\
\hline G. niger & $0+$ & $\begin{array}{c}- \\
\ldots \ldots\end{array}$ & $\begin{array}{c}0.48 \\
\ldots \ldots .\end{array}$ & $\begin{array}{c}- \\
. \\
\ldots\end{array}$ & $\begin{array}{l}- \\
-\end{array}$ & 0.07 & - & - & $\begin{array}{l}0.48 \\
0.07\end{array}$ \\
\hline P.phoxinus & & - & 0.58 & - & - & - & - & - & 0.58 \\
\hline \multicolumn{10}{|l|}{ P. microps } \\
\hline P. minutus & $0+$ & $\begin{array}{c}- \\
\ldots \ldots\end{array}$ & $\begin{array}{l}0.28 \\
\ldots\end{array}$ & $\begin{array}{l}0.75 \\
\ldots\end{array}$ & $-\overline{87}$ & $\begin{array}{l}0.07 \\
0.20\end{array}$ & $-\overline{10}$ & $-\overline{52}$ & $\begin{array}{ll}0.37 & (0.28) \\
0.42 & (0.30)\end{array}$ \\
\hline G. niger & $0+$ & $\begin{array}{c}- \\
\ldots .\end{array}$ & $\begin{array}{c}0.39 \\
\ldots \ldots\end{array}$ & $\begin{array}{c}- \\
\ldots \\
\ldots\end{array}$ & $\begin{array}{l}- \\
-\end{array}$ & $-\overline{61}$ & $\overline{0} 83$ & 0.25 & $\begin{array}{l}0.39 \\
0.56(0.24)\end{array}$ \\
\hline P. phoxinus & & - & 0.11 & - & - & 0 & - & - & $0.06(0.06)$ \\
\hline \multicolumn{10}{|l|}{$P$. minutus } \\
\hline G. niger & $0+$ & - & .4. & $\begin{array}{l}- \\
\ldots\end{array}$ & - & $-\overline{20}$ & 0.12 & $\overline{0.09}$ & $\begin{array}{ll}0.44 & \\
0.14 & (0.05)\end{array}$ \\
\hline$P$. phoxinus & & - & 0.49 & - & - & 0.61 & 0.40 & 0.09 & $0.40(0.19)$ \\
\hline \multicolumn{10}{|l|}{ G. niger } \\
\hline P. phoxinus & & - & 0.40 & - & - & - & - & - & 0.40 \\
\hline $\begin{array}{l}\text { Mean food overlap } \\
\text { for fish assemblage }\end{array}$ & $0+$ & $\begin{array}{c}0.33 \\
\ldots \ldots\end{array}$ & $\begin{array}{c}0.45 \\
\ldots \ldots\end{array}$ & $\begin{array}{c}0.50 \\
\ldots \ldots\end{array}$ & $\begin{array}{l}0.71 \\
0.74\end{array}$ & $\begin{array}{l}0.23 \\
0.41\end{array}$ & $\begin{array}{l}0.40 \\
0.35\end{array}$ & $\begin{array}{l}0.09 \\
0.27\end{array}$ & \\
\hline
\end{tabular}

The wider food niches during the spawning season were probably due to territorial behaviour; in that case they would speak neither for nor against the significance of food competition, especially since the territorial behaviour and the parental care have evolved in shallow areas as a response to the scarcity of safe nest sites (Wilbour et al., 1974) and not to food shortage. Generally speaking, no evidence has been found to support the idea of food competition as an important structuring factor. Sale (1977) and Robertson (1980) concluded that competitive processes in fish communities had possibly been overemphasized and that coexistence may occur without any resource partitioning. Our results point in the same direction, at least regarding the food-resource dimension.

The population density of fish in the present area (Table 1) was about $40 \%$ of that on the Swedish west coast (Thorman, 1982), taking into account the differences in sampling methods. The efficiency of the hand trawl method, used in this study, was $50 \%$ of the dropnet method (own unpubl. data).

The lower number of individuals in the present area cannot be explained by relative resource scarcity because there is hardly any difference between mac- 
Table 4. Total length (standard deviation in brackets) $(\mathrm{mm})$ of the 3 fish species studied 1980 at Väddö, southern Bothnian Sea, and 1978 in river Broälven estuary, Swedish west-coast. Student's t-test

\begin{tabular}{|c|c|c|c|c|c|}
\hline Species & Area & Oct & Apr & $\Delta \mathrm{l}$ & \\
\hline \multirow[b]{2}{*}{ P. pungit } & Väddö & $\begin{array}{l}36.20(3.75) \\
n=143\end{array}$ & $\begin{array}{l}35.52(4.10)^{1} \\
n=65\end{array}$ & -0.68 & NS \\
\hline & Broälven estuary & $\begin{array}{l}37.45(4.24) \\
n=461 \\
\Delta 1=1.25 \\
p<0.001\end{array}$ & $\begin{array}{l}50.99(8.09)^{1} \\
n=10 \\
\Delta l=15.47 \\
p<0.001\end{array}$ & 13.54 & $\mathrm{p}<0.001$ \\
\hline \multirow[b]{2}{*}{ G. aculec } & Väddö & $\begin{array}{l}32.27(5.46) \\
n=74\end{array}$ & $\begin{array}{l}31.78 \\
n=9\end{array}$ & -0.49 & NS \\
\hline & Broälven estuary & $\begin{array}{l}40.92(6.67) \\
n=324 \\
\Delta l=8.65 \\
p<0.001\end{array}$ & $\begin{array}{l}48.52(8.14) \\
n=73 \\
\Delta l=16.74 \\
p<0.001\end{array}$ & 7.60 & $\mathrm{p}<0.001$ \\
\hline \multirow[b]{2}{*}{ P. microp } & Väddö & $\begin{array}{l}24.57 \\
n=24\end{array}$ & $\begin{array}{l}24.00(2.27) \\
n=15\end{array}$ & -0.57 & NS \\
\hline & Broälven estuary & $\begin{array}{l}27.66(5.98) \\
n=1048 \\
\Delta l=3.09 \\
p<0.001\end{array}$ & $\begin{array}{l}31.50(8.63) \\
n=65 \\
\Delta I=7.50 \\
p<0.001\end{array}$ & 3.84 & $p<0.001$ \\
\hline
\end{tabular}

rofauna biomass in the southern Bothnian Sea and the west-coast area (Elmgren, 1978; Rosenberg and Möller, 1979). Predation and parasitism may also be important for fish populations, but evidence is lacking in the 2 areas.

During winter no growth was observed in Pungitius pungitius, Gasterosteus aculeatus and Pomatoschistus microps in the southern Bothnian Sea, but on the west coast these 3 species grew during the same period (Table 4). No data for $P$. minutus were available from the west-coast area. The average sizes of these 3 fish species in the southern Bothnian Sea were smaller compared to the fish on the west coast (Table 4).

The fact that numbers and sizes of the fish were smaller in the southern Bothnian Sea than in the westcoast area is probably a result of differences in abiotic conditions between the 2 areas. In the southern Bothnian Sea the ice period is about 1.5 mo longer, periods with temperatures of $\geq 15^{\circ} \mathrm{C}$ about 3 mo shorter and the salinity 10 to $20 \% \mathrm{~S}$ lower compared to the westcoast (Wändahl and Bergstrand, 1973; Thorman, 1982).

Low temperature and salinity $\approx 5 \%$ S have a negative effect on food intake, growth and reproduction (Brett, 1970; Garside, 1970; Holliday, 1971) and thus cause fish abundance to become lower than under more favourable conditions.

In conclusion, we found no evidence that food competition exerted an important impact on structuring the present fish assemblage. Unfavourable abiotic conditions are probably responsible for the low population density and productivity of the Bothnian fish population. Thus, abiotic factors appear to keep these populations below the abundance level at which food scarcity could result in important selective pressure.

Acknowledgements. We thank D. Morse, S. Ulfstrand and A. Berglund for valuable comments on the manuscript. The study was supported by grants from the National Swedish Environment Protection Board.

\section{LITERATURE CITED}

Adams, S. M. (1976). The ecology of eelgrass, Zostera marina L. fish communities. I. Structural analysis. J. exp. mar. Biol. Ecol, 22: 269-293

Anéer, G., Nellbring, S. (1977). A drop-trap investigation of the abundance of fish in very shallow water in the Askö area, northern Baltic proper. In: Keegan, B. F., Ceidigh, P. O., Boaden, P. J. S. (eds.) Biology of benthic organisms. Pergamon Press, Oxford, pp. 21-30

Brett, J. R. (1970). 3. Temperature: Animals: Fishes. In: Kinne, O. (ed.) Marine ecology, Vol. 1, Environmental factors, Part 1. Wiley-Interscience, London, pp. 515-560

Cody, Martin L. (1974). Competition and structure of bird communities, Princeton University Press, Princeton, New York

Colwell, R. K., Futuyma, D. J. (1971). On the measurements of niche breadth and overlap. Ecology 52: 567-576 
Connell, J. H. (1975). Some mechanisms producing structure in natural communities: a model and evidence from field experiments. In: Cody, M., Diamond, J. N. (eds.) Ecology and evolution of communities, Belknap, Harvard

Connell, J. H. (1980). Diversity and the coevolution of competitors, or the ghost of competition past. Oikos 35 : $131-138$

Elmgren, R. (1978). Structure and dynamics of Baltic benthos communities, with particular reference to the relationship between macro- and meiofauna. Kieler Meeresforsch. 4 $1-22$

Garside, E. T. (1970). Temperature: Animals: Fishes. In: Kinne, O. (ed.) Marine ecology, Vol. I, Environmental factors, Part 1. Wiley-Interscience, London, pp. 561-573

Holliday, F. G. T. (1971). Salinity: Animals; Fishes. In: Kinne, O. (ed.) Marine ecology, Vol. I, Environmental factors, Part 2. Wiley-Interscience, London, pp. 377-1083

Hurlbert, S. H. (1978). The measurement of niche overlap and some relatives. Ecology 59: 67-77

Khlebovich, V V. (1968). Some peculiar features of the hydrochemical regime and the fauna of mesohaline waters. Mar. Biol. 2: 47-49

Kislalioglu, M., Gibson, R. N. (1977). The feeding relationship of shallow water fishes in a Scottish sea loch. J. Fish Biol. 11: $257-266$

Lemmetyinen, R. (1973). Feeding ecology of Sterna paradisea Pontopp. and $S$. hirundo $\mathrm{L}$. in the archipelago of southwestern Finland. Ann. Zool. Fennici 10: 507-525

MacArthur, R. H. (1972). Geographical ecology, Harper and Row. Publ., New York

Nilsson, N.-A. (1960). Seasonal fluctuations in the food segregation of trout, char and whitefish in 14 North-Swedish lakes. Rep. Inst. Freshw. Res., Drottningholm 41: 185-205
Robertson, A. I. (1980). The structure and organization of an eelgrass fish fauna. Oecologia (Berl.) 47: 76-82

Rohwer, S. (1978). Parent cannibalism of offspring and egg raiding as a courtship strategy. Am. Nat. 112: $429-440$

Rosenberg, R., Möller, P. (1979). Salinity stratified benthic macrofaunal communities and long-term monitoring along the west coast of Sweden. J. exp. Mar. Biol. Ecol. 37 $175-203$

Roughgarden, J. (1974). Species packing and the competition function with illustrations from coral reef fish. Theor. Pop Biol. 5: 163-186

Sale, P. F. (1977). Maintenance of high diversity in coral reef fish communities. Am. Nat. 111: 337-359

Shannon, C. E., Weaver, W. (1949). The mathematical theory of communication, Urban Ill, University Illinois Press

Svärdson, G. (1976). Interspecific population dominance in fish communities of Scandinavian lakes. Rep. Inst. Freshw. Res., Drottningholm 32: 79-95

Thorman, S. (1982). Niche dynamic and resource partitioning in a fish guild inhabiting a shallow estuary in the Swedish west coast. Oikos 39: 32-39

Werner, E. E., Hall, D. J. (1977). Competition and habitat shift in two sunfishes (Centrarchidae). Ecology 58: 869-876

Wändahl, E., Bergstrand, E. (1973). Oceanografiska förhållanden i svenska kustvatten, Serie: Hydrologi Nr 27, Sveriges Meteorologiska och Hydrologiska Institut

Wilbur, H. M., Tinkle, D. W., Collins, J. P. (1974). Environmental certainty, trophic level and resource availability in life history evolution. Am. Nat. 108: 805-817

Zander, C. D. (1979). On the biology and food of small sized fish from the North and Baltic sea areas. II. Investigation of a shallow stony ground off Møn, Denmark. Ophelia 18 : $179-190$ 